\title{
Adsorption behavior at interface of oil-in-water emulsions prepared with mixtures of milk fat globule membrane proteins and polar lipids
}

\author{
${ }^{1, * \text { Phan, T.T.Q., }}{ }^{2}$ Le, T.T. and ${ }^{3}$ Dewettinck, K. \\ ${ }^{1}$ Department of Food Technology, College of Agriculture, Can Tho University, 3/2 street, Ninh Kieu \\ District, Can Tho City, Viet Nam \\ ${ }^{2}$ Faculty of Food Science and Technology, Nong Lam University, Thu Duc District, Ho Chi Minh City, \\ Vietnam \\ ${ }^{3}$ Laboratory of Food Technology and Engineering, Department of Food Safety and Food Quality, Ghent \\ University, Coupure Links 653, B-9000 Ghent, Belgium
}

\begin{abstract}
Article history:
Received: 15 April 2020

Received in revised form: 18 May 2020

Accepted: 31 May 2020

Available Online: 28 June 2020
\end{abstract}

\section{Keywords:}

Emulson,

Milk fat globule membrane,

Protein,

Polar lipids

DOI:

https://doi.org/10.26656/fr.2017.4(5).167

\begin{abstract}
The milk fat globule membrane (MFGM) contains proteins and polar lipids making this complex mixture a good emulsifier. In this study, MFGM material was isolated from reconstituted buttermilk using microfiltration and further separated into MFGM protein concentrate and polar lipid concentrate using solvent fractionation. The emulsifying properties of those two emulsifier fractions, separately or in combination, at various concentrations of proteins $(0.3 ; 1.3$ and $2.3 \mathrm{w} \%)$ and polar lipids $(0.3 ; 1.3$ and $2.3 \mathrm{w} \%)$, were investigated. The results showed that at low emulsifier concentrations $(<2.3 \%)$, the combination of both proteins and polar lipids resulting in the formation of emulsions with a small droplets size and low apparent viscosity. The addition of polar lipids did not replace the adsorbed proteins. Between the two emulsifier fractions, MFGM protein concentrate had greater emulsifying properties compared to the polar lipid concentrate.
\end{abstract}

\section{Introduction}

Milk fat globule membrane (MFGM), a thin film surrounding the fat globules in milk, contains mainly membrane-specific proteins and polar lipids (PLs) (Walstra et al., 2006). Both MFGM proteins and PLs have technological functionalities and can be used as emulsifying agents due to their amphiphilic nature (Kanno et al., 1991, Roesch et al., 2004, Vanderghem et al., 2010). The use of such an enriched PLs isolate emulsifier has been reported by Miura et al. (2006). Ihara et al. (2011) reported that reconstituted cream made with buttermilk containing high PLs concentration was more stable, had a higher droplet surface area and was more acid-tolerant than cream made with buttermilk containing low PLs concentration. Along with PLs, proteins also have amphiphilic characteristics and can act as surface-active compounds (Singh, 2011). They are able to stabilize emulsion droplets due to their ability to absorb, and unfold rapidly, at the oil-water interface. Shimizu et al. (1980) reported, as one of the first, on the emulsifying properties of MFGM proteins and PLs as regards the stabilization of the fat globules in milk. The authors digested MFGM proteins, obtained from washed cream with papain and then used them in cream. Due to the clustering of fat globules, a decrease in the stability of the cream was observed. It was concluded that proteins and glycoproteins in MFGM are able to play an important role in emulsion stabilization.

However, the influence of MFGM-specific proteins and PLs, separately, or the alteration in interactions of PLs with other components of the membrane (e.g. whey proteins, caseins and MFGM-specific proteins) at the oil droplet surface during emulsification, have not been elucidated. Sodini et al. (2006) reported that whey buttermilk resulting from the churning of whey cream in the manufacture of whey butter gave higher emulsifying properties and lower foaming ability compared to sweet or cultured buttermilk, due to a higher ratio of phospholipids to proteins. Phan et al. (2013) also found that MFGM fragments, obtained from reconstituted buttermilk by microfiltration, had better emulsifying and stabilizing properties as compared to buttermilk powder, skim milk powder and sodium caseinate, probably due to a higher concentration of PLs. However, contrary to what would be expected, emulsions prepared with MFGM isolated from buttermilk whey did not have good emulsifying properties as compared to MFGM isolated from reconstituted buttermilk and LacprodanPL-20, 
despite the higher concentration in PLs (Phan et al., 2014). It was stated that not only the PLs content but also the presence of other components (e.g. whey proteins, caseins, MFGM-specific proteins and minerals). Especially the level of the other substances and their possible interactions with the different MFGM materials did determine the emulsifying properties. The data published by Wong and Kitts (2003) also suggested that not the MFGM components but rather the ratio between the level of casein, whey and MFGM in buttermilk, determine the functional properties. Thus far, no information is available on the possible effect of PLs and MFGM proteins on the surface-active properties as well as on the competitive adsorption behavior between the two component groups at the interface of $\mathrm{O} / \mathrm{W}$ emulsions. In the present study, in order to get a better understanding of the role of MFGM proteins and PLs or on possible competitive adsorption at the interface surface of oil-in-water emulsions, the effect of various concentrations of MFGM proteins and PLs, obtained from MFGM material isolated from reconstituted buttermilk, was investigated.

\section{Materials and methods}

\subsection{Materials}

Buttermilk powder was obtained from FrieslandCampina (Lummen, Belgium). Soybean oil was purchased from a local supermarket. Analytical chemicals were purchased from Fisher Scientific (Erembodegem, Belgium) and Chem-Lab (Zedelgem, Belgium). The XCell SureLock Mini-Cell Electrophoresis System, all reagents, and the gradient gels (Novex NuPAGE 4-12\% Bis-Tris $1 \mathrm{~mm} \times 17$ wells) were purchased from Invitrogen (Merelbeke, Belgium).

\subsection{Preparation of MFGM protein and PL concentrate}

Cross-flow microfiltration was applied to isolate MFGM material from reconstituted buttermilk as described by Phan et al. (2013). The term 'whole MFGM material' was used to describe the MFGM material obtained after microfiltration. Whole MFGM material was separated into a MFGM protein concentrate and a PL concentrate using solvent fractionation according to the procedure described by Phan et al. (2016). The extracts obtained from the upper and lower phase were called MFGM protein and PL concentrate, respectively. The composition of MFGM protein and PL concentrate was analyzed as described in a previous paper (Phan et al., 2014). The MFGM protein concentrate contained $83.98 \%$ total proteins on a dry basis $(\mathrm{w} / \mathrm{w})$. PL concentrate contained 39.7\% PLs in total lipids (w/w). Prior to emulsion preparation, MFGM protein and PL concentrate was stored at below $-20^{\circ} \mathrm{C}$ (Phan et al.,
2016)

\subsection{Emulsion preparation}

Oil-in-water emulsions were prepared with $35 \%$ soybean oil using different combinations of MFGM protein and PL concentrate according to the procedure described by Phan et al. (2016). In our procedure, PL concentrate $\left(0,0.3,1.3\right.$ and $2.3 \mathrm{~g}$ PLs $100 \mathrm{~g}^{-1}$ emulsion) was dispersed in soybean oil under stirring (magnetic stirrer). The aqueous phase containing MFGM protein concentrate $\left(0,0.3,1.3\right.$ and $2.3 \mathrm{~g}$ proteins $100 \mathrm{~g}^{-1}$ emulsion) was prepared by dispersion in deionized water. Next, the oil and aqueous phase were mixed and heated to $50^{\circ} \mathrm{C}$ and the mixture was pre-homogenized using an Ultra-Turrax T25 basic (IKA ${ }^{\circledR}$ Werke $\mathrm{GmbH}$ and Co. KG, Staufen, Germany) at 13,000 rpm for $2 \mathrm{~min}$. The homogenization was performed in a two-step laboratory-scale high-pressure homogenizer (APV cooling systems, Alberslund, Denmark) at 9 and $2 \mathrm{MPa}$ for the first and second step, respectively. After homogenization and prior to characterization, the emulsions were stored at $4^{\circ} \mathrm{C}$. Three replicate emulsions were prepared for each combination of MFGM protein and PL concentrate.

\subsection{Determination of physicochemical properties of emulsions}

\subsubsection{Microscopic observation}

Microscopic observation of the emulsions was carried out at room temperature after one day of storage, according to the procedure of Phan et al. (2013). The images were observed at $50 \times$ magnification using a Leitz Diaplan microscope (Leitz diaplan Leica, Solms, Germany). The images were recorded with a built-in Olympus Color View camera and processed with cell* D software (Olympus, Aartselaar, Belgium).

\subsubsection{Rheological characteristics}

The flow behavior of the samples was measured after one day of storage at $4{ }^{\circ} \mathrm{C}$ using a TA instrument AR2000 controlled-stress rheometer (New Castle, DE, USA) as described by Phan et al. (2013). The experimental data were fitted to the power law equation [1]:

Shear stress $=K \mathrm{x}(\text { Shear rate })^{n}$

Where $K$ is the consistency index and $n$ the flow behavior index.

\subsubsection{Determination of adsorption behavior of proteins and PLs at the oil-water interface}

The protein profile of the emulsions, the individual adsorbed proteins at the surface of the oil droplets (i.e., 
cream phase) and the non-absorbed proteins in the serum phase were determined using SDS-PAGE

according to Phan et al. (2014). The load on each sample lane was $13 \mu \mathrm{g}$ of total proteins. Electrophoresis was performed according to the protocol of Invitrogen with SimplyBlue SafeStain (Coomassie Blue). The wet gel was scanned at 400 dots per inch (dpi) using a highresolution transmission scanner (UMAX PowerLook III, UMAX Technologies, Taipei, Taiwan). Identification of proteins was performed by comparing the protein bands to the molecular weight of Mark12 Protein Standard (Invitrogen). The band intensities of proteins in the emulsion, cream phase and serum phase were compared. The proportion of an individual protein [xanthine oxidase (XO), butyrophilin (BTN), caseins, $\beta$ lactoglobulin $(\beta$-LG) or $\alpha$-lactalbumin $(\alpha-\mathrm{LA})]$ adsorbed at the surface of the oil droplets (i.e., cream phase) to the protein in the emulsion (i.e., in the cream phase plus serum phase) was calculated using densitometry on SDSPAGE according to Phan et al. (2014) based on equation [2]:

$\begin{gathered}\text { Surface } \\ \begin{array}{c}\text { proportion of a } \\ \text { specific protein } \\ (\%)\end{array}\end{gathered}=\frac{\begin{array}{c}\text { Band intensity of the protein in } \\ \text { cream phase }\end{array}}{\begin{array}{c}\text { Total band intensity of the } \\ \text { protein in cream and serum } \\ \text { phases }\end{array}} \times 100$

Similar to the determination of adsorbed proteins, the adsorption of a specific polar lipid at the surface of the oil droplets was determined. The PLs content in the cream phase and in the emulsion was analyzed, after extraction, using a Shimadzu HPLC system (Shimadzu Corp., Tokyo, Japan) with an evaporative light scattering detector (Alltech-3300, Alltech Associates Inc., Lokeren, Belgium) according to the method of Le et al. (2011). The proportion of an individual PL component [glucosylceramide (GluCer), lactosylceramide (LacCer), phosphatidylinositol (PI), phosphatidylethanolamine (PE), phosphatidylserine (PS), phosphatidylcholine (PC), and sphingomyelin (SM)] in the cream phase compared to that of the polar lipid component in the emulsion, was calculated according to the following equation [3]:

\footnotetext{
Surface Concentration of a polar lipid

\subsection{Statistical analysis}

Statistical analysis was performed using SPSS version 21 (IBM Inc., Chicago, IL., USA). One-way analysis of variance (ANOVA) and Tukey's test was used for multiple comparisons of means. A two-way ANOVA was performed to compare the interaction of the effects of various levels of two factors in a factorial experiment. The differences were considered statistically significant at $P \leq 0.05$. Multivariate principal component analysis (PCA) is a data reduction technique that compresses the number of correlated variables into a smaller number of uncorrelated variables (i.e., principal components). The average value of the relative proportion of absorbed proteins (XO, BTN, caseins, $\beta$ LG, and $\alpha$-LA) and adsorbed PLs (GluCer, LacCer, PI, $\mathrm{PE}, \mathrm{PS}, \mathrm{PC}$, and $\mathrm{SM}$ ) at the surface of the emulsion prepared with different concentration combinations of MFGM protein and PL concentrate was evaluated using PCA with Varimax rotation.

\section{Results and discussion}

\subsection{Microscopic observation}

The differences in the degree of flocculation of emulsions as affected by protein and polar lipid content can be seen in Figure 1.
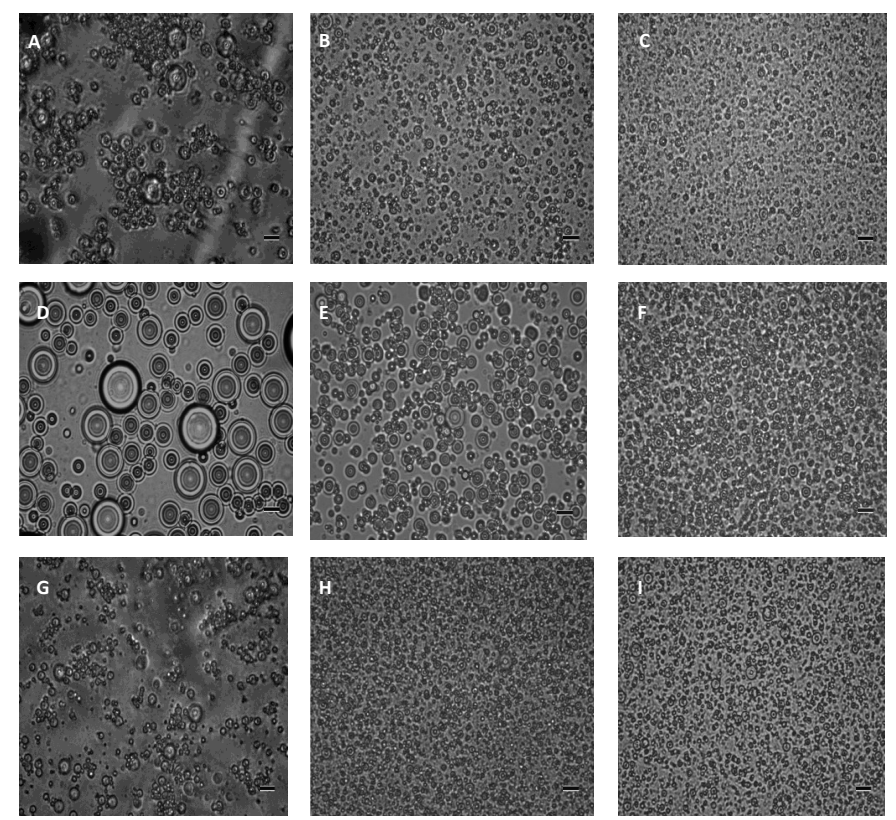

Figure 1. Microscopic images of emulsions prepared with varying concentrations of proteins and/or PLs (A: $0.3 \%$ proteins; B: $1.3 \%$ proteins; C: $2.3 \%$ proteins; D: $0.3 \%$ PLs; E: 1.3\% PLs; F: $2.3 \%$ PLs; G: $0.3 \%$ proteins- $0.3 \%$ PLs; H: $1.3 \%$ proteins $-1.3 \%$ PLs; I: $0.3 \%$ proteins $-2.3 \%$ PLs). The scale bars indicate $50 \mu \mathrm{m}$.

Microscopic imaging revealed that the emulsions prepared with PLs $0.3 \%$ were characterized by large droplets probably due to coalescence (Figure 1D), whereas flocculation occurred in emulsions prepared with $0.3 \%$ proteins alone or in combination with $0.3 \%$ PLs (Figure 1A and 1G). Flocculation can occur due to bridging in emulsions prepared with a low concentration of proteins (Roesch et al., 2004). Tomas and Paquet (1994) also showed that the aggregation of fat droplets in emulsions is due to the presence of an insufficient amount of proteins. During emulsion preparation, 
homogenization or ultra-mixing are commonly applied to reach a uniform texture. High homogenization pressure reduces the droplet sizes and, thereby, increases the surface area. Consequently, surface-active agents need to be adsorbed at the interface in order to reduce the surface tension and to stabilize the emulsion; therefore, sufficient amphiphilic molecules have to be present to cover the surface area (Kanno et al., 1991). By increasing the concentration of proteins and/or PLs in the emulsion or both, the droplet size was decreased and no indication of aggregation was noticed (Figure 1B, C, F, H and I).

\subsection{Rheological behavior}

The plots of apparent viscosity versus shear rates of the emulsions as affected by varying proteins and/or PLs content are shown in Figure 2. Flow curve parameters are summarized in Table 1.
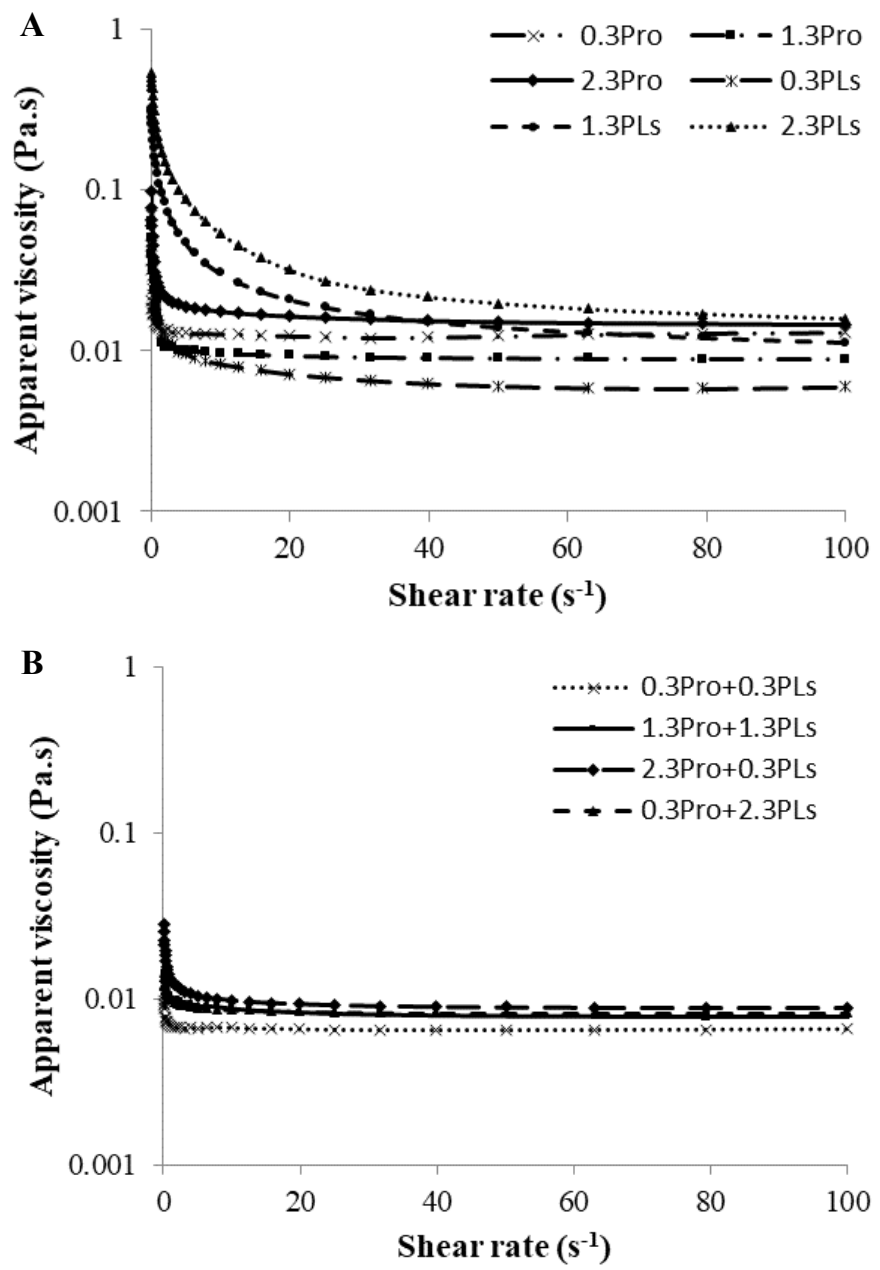

Figure 2. Apparent viscosity of the emulsions prepared with various concentrations of either proteins or PLs (A) and with some combinations of proteins and PLs (B).

All emulsions showed pseudoplastic flow behavior, as the apparent viscosity decreased with increasing shear rates (Figure 2). At $100 \mathrm{~s}^{-1}$, the effect of PLs on the apparent viscosity of emulsions strongly depended on the concentration of the proteins. In the absence of proteins, the apparent viscosity increased markedly with an increase in PL concentrations from $0.3 \%$ to $2.3 \%$ (Figure 2A). In emulsions prepared with proteins, whether or not combined with PLs, increasing the protein concentrations led to an increase in the apparent viscosity (Figure 2 and Table 1). This rheological behavior could be due to increased adsorption of proteins at the interface (Figure 4A and B). The lateral interaction among proteins at the interface leads to the formation of a viscoelastic layer and an increase in viscosity (Murray and Dickinson, 1996). In addition, Chanamai and McClements (2000) reported that the apparent viscosity of oil-in-water emulsions was strongly influenced by the sizes and concentrations of emulsion droplets. These authors showed that the apparent viscosity of emulsions increased with decreasing droplet sizes and by an increase in the droplet concentrations (Chanamai and McClements, 2000). Since an increase in the concentrations of either proteins or PLs, or both, caused a reduction in the droplet size (Figure 1), there was more interparticle resistance to flow. Hence, a higher concentration in proteins and/or PLs led to higher apparent viscosity. At low emulsifier concentrations, the emulsions prepared with $0.3 \%$ proteins showed a higher apparent viscosity than those prepared with $1.3 \%$ proteins (Figure 2A). Similar behavior was observed with emulsions prepared with $0.3 \%$ proteins and $0.3 \%$ PLs compared to those prepared with other combinations (Figure 2B). This may probably be due to the breakup of aggregates under the effect of a high shear rate (Dickinson and Golding, 1997). The flow data are consistent with the microscopic observations.

The flow data fitted well to the power law model, as indicated by the $\mathrm{R}^{2}>0.97$ for all emulsions. Consequently, the consistency index $K$ and flow behavior index $n$ can be used to describe the flow behavior of these emulsions (Table 1). All emulsions prepared with proteins $(0.3-2.3 \%)$ whether or not in combination with PLs (0.3-2.3\%), showed a flow behavior close to that of Newtonian liquids ( $n$ approaching 1) and a relatively low consistency index $K$ (Table 1). In contrast, emulsions prepared with PLs (0.3$2.3 \%$ ) showed a pronounced shear-thinning behavior. Since the extracted PLs concentrate still had a high lipid content, the lipid phase was probably incorporated in the oil phase by dilution. This can be a reason for the observed high consistency index $(K)$ in emulsions prepared with PLs when the concentration of PLs used was high. Scott et al. (2003) reported that the higher PLs and unsaturated fatty acid content (oleic and linoleic acid) of MFGM fragments resulted in an increase in the fluidity of the emulsions. The increasing trend of the consistency index $K$ caused by the concentration of proteins and PLs were consistent with the changing trend of the apparent viscosity. 
Table 1. Flow parameters of emulsions as affected by varying proteins and PLs content

\begin{tabular}{cccccc}
\hline Proteins (wt\%) & PLs (wt\%) & $K\left(P a . s^{n}\right)$ & $\mathrm{n}(-)$ & $\eta^{*}(\mathrm{mPa} . \mathrm{s})$ at shear rate $100 \mathrm{~s}^{-1}$ & $\mathrm{R}^{2}$ \\
\hline 0.3 & 0.0 & $0.017 \pm 0.003^{\mathrm{abc}}$ & $0.90 \pm 0.09^{\mathrm{cd}}$ & $12.97 \pm 0.98^{\mathrm{ef}}$ & 0.980 \\
1.3 & 0.0 & $0.014 \pm 0.001^{\mathrm{abc}}$ & $0.89 \pm 0.05^{\mathrm{cd}}$ & $8.85 \pm 0.64^{\mathrm{cd}}$ & 0.980 \\
2.3 & 0.0 & $0.027 \pm 0.005^{\mathrm{c}}$ & $0.84 \pm 0.08^{\mathrm{cd}}$ & $14.45 \pm 0.05^{\mathrm{fg}}$ & 0.996 \\
0.0 & 0.3 & $0.016 \pm 0.001^{\mathrm{abc}}$ & $0.67 \pm 0.03^{\mathrm{b}}$ & $5.96 \pm 0.54^{\mathrm{a}}$ & 0.988 \\
0.0 & 1.3 & $0.120 \pm 0.016^{\mathrm{e}}$ & $0.46 \pm 0.02^{\mathrm{a}}$ & $11.23 \pm 0.20^{\mathrm{e}}$ & 0.989 \\
0.0 & 2.3 & $0.194 \pm 0.008^{\mathrm{f}}$ & $0.44 \pm 0.01^{\mathrm{a}}$ & $15.85 \pm 0.17^{\mathrm{g}}$ & 0.980 \\
0.3 & 0.3 & $0.008 \pm 0.001^{\mathrm{ab}}$ & $0.94 \pm 0.03^{\mathrm{de}}$ & $6.37 \pm 0.53^{\mathrm{a}}$ & 0.998 \\
1.3 & 0.3 & $0.008 \pm 0.000^{\mathrm{ab}}$ & $0.93 \pm 0.02^{\mathrm{de}}$ & $6.68 \pm 0.02^{\mathrm{ab}}$ & 0.999 \\
2.3 & 0.3 & $0.016 \pm 0.002^{\mathrm{abc}}$ & $0.84 \pm 0.00^{\mathrm{cd}}$ & $9.07 \pm 0.69^{\mathrm{cd}}$ & 0.998 \\
0.3 & 1.3 & $0.006 \pm 0.000^{\mathrm{a}}$ & $0.97 \pm 0.00^{\mathrm{e}}$ & $5.71 \pm 0.07^{\mathrm{a}}$ & 0.996 \\
1.3 & 1.3 & $0.013 \pm 0.001^{\mathrm{abc}}$ & $0.88 \pm 0.02^{\mathrm{cd}}$ & $8.10 \pm 0.51^{\mathrm{bc}}$ & 0.996 \\
2.3 & 1.3 & $0.023 \pm 0.006^{\mathrm{bc}}$ & $0.80 \pm 0.02^{\mathrm{c}}$ & $10.34 \pm 0.66^{\mathrm{de}}$ & 0.999 \\
0.3 & 2.3 & $0.011 \pm 0.002^{\mathrm{ab}}$ & $0.92 \pm 0.03^{\mathrm{de}}$ & $8.43 \pm 0.69^{\mathrm{c}}$ & 0.999 \\
1.3 & 2.3 & $0.017 \pm 0.002^{\mathrm{abc}}$ & $0.88 \pm 0.01^{\text {cd }}$ & $10.28 \pm 0.87^{\mathrm{de}}$ & 0.999 \\
\hline
\end{tabular}

Values are expressed as mean values $\pm \mathrm{SD}$ of three replicates. Values within a column followed by different superscripts are significantly different (Tukey's test, $\mathrm{P} \leq 0.05$ ).

\subsection{Adsorption behavior of proteins and PLs at the interface of oil-water emulsions}

The adsorbed proteins at the surface of emulsions prepared with various concentrations of proteins and PLs were analysed by comparing the SDS-PAGE pattern of the cream phase with that of the serum phase (Figure 3).

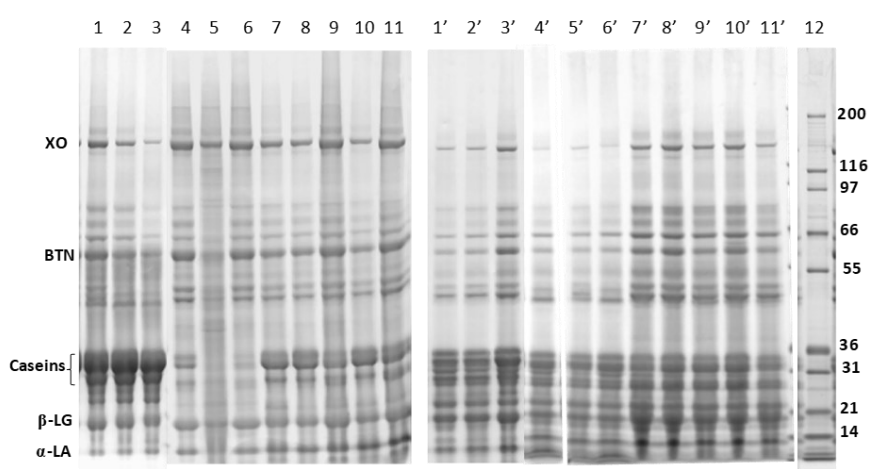

Figure 3. SDS-PAGE patterns of different samples. Lanes 13: cream phase of emulsions prepared with $0.3,1.3$ and $2.3 \%$ proteins, respectively; Lanes 1'-3': serum phase of emulsions prepared with $0.3,1.3$ and $2.3 \%$ proteins, respectively; Lanes 4 and 4': cream and serum phase of emulsion prepared with $0.3 \%$ proteins and $0.3 \%$ PLs; Lanes 5 and 5 ': cream and serum phase of emulsions prepared with $0.3 \%$ proteins and $1.3 \%$ PLs; Lanes 6 and 6': cream and serum phase of $0.3 \%$ proteins and 2.3\% PLs; Lanes 7 and 7': cream and serum phase of $1.3 \%$ proteins and $0.3 \%$ PLs; Lanes 8 and 8 ': cream and serum phase of $1.3 \%$ proteins and $1.3 \%$ PLs; Lanes 9 and 9': cream and serum phase of $1.3 \%$ proteins and $2.3 \%$ PLs; Lanes 10 and 10': cream and serum phase of $2.3 \%$ proteins and $0.3 \%$ PLs; Lanes 11 and 11': cream and serum phase of 2.3\% proteins and 1.3\% PLs; Lane 12: molecular mass $(\mathrm{kg} /$ mol) standards. The load on each lane was $13 \mu \mathrm{g}$ total proteins.

SDS-PAGE of the cream and serum phase of the emulsions following centrifugation showed that with the increase in the protein concentration, the high band intensities of proteins were observed in the serum phase. At constant protein concentration, the PL concentration in the system does not seem to affect the $\beta$-LG and $\alpha$-LA band intensities in the serum phase as well as in the cream phase. At $0.3 \%$ proteins combined with various PL concentrations (0.3-2.3\%), almost all XO and BTN were adsorbed at the oil droplet surface, i.e. the serum phase contained only traces of these proteins (Lane 4'6'). Contrary to XO and BTN, a low band intensity of caseins was observed in the cream phase (lane 4-6). When increasing the protein concentrations, regardless of the PLs concentrations, the serum phase contained a considerable amount of proteins. In such samples, $\mathrm{XO}$, BTN, caseins, $\beta$-LG, and $\alpha$-LA were absent in the serum phase at $0.3 \%$ proteins, but at higher concentrations $(\geq$ $1.3 \%$ ) not only the bands of XO and BTN but also the bands of $\beta$-LG, and $\alpha$-LA appeared in the serum phase.

The relative proportion of individual adsorbed protein in the cream phase and in the original emulsion (i.e. the sum of that protein in the cream phase and in the serum phase), was estimated using color intensity analysis, as shown in Figure 4. The adsorption behavior of individual PLs at the surface of oil-in-water emulsions, prepared with various concentrations of proteins and PLs is shown in Figure 5.

The result clearly shows that the adsorbed proportion of XO and BTN at the surface of emulsions prepared with both proteins and PLs was higher than that of emulsions prepared with proteins, solely (Figure 4A). This may indicate that the presence of PLs enhanced the adsorption of $\mathrm{XO}$ and BTN at the droplet surface 


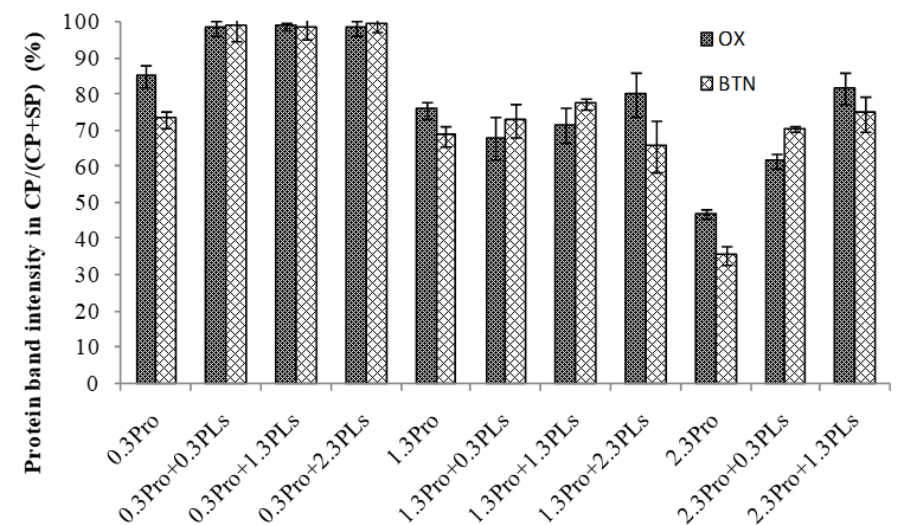

A

Combination of proteins and polar lipids (wt\%)

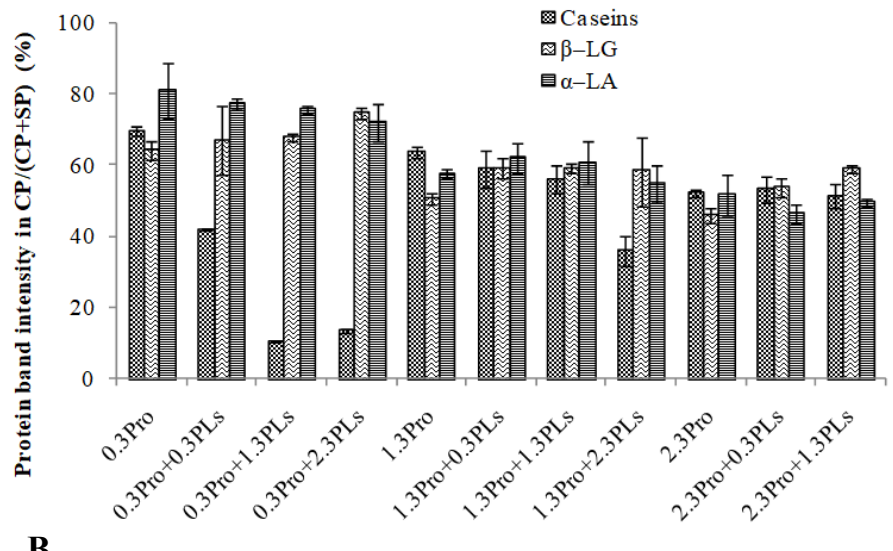

B

Combination of proteins and polar lipids (wt\%)

Figure 4. Sodium dodecyl sulfate PAGE band intensity of (A) MFGM-specific proteins (XO, BTN) and (B) non-MFGM proteins (caseins, $\beta$-LG, $\alpha$-LA) in cream phase relative to the sum of those in cream and serum phase of emulsions prepared with various concentrations of proteins and PLs. $\mathrm{CP}=$ cream phase; $\mathrm{SP}=$ serum phase.

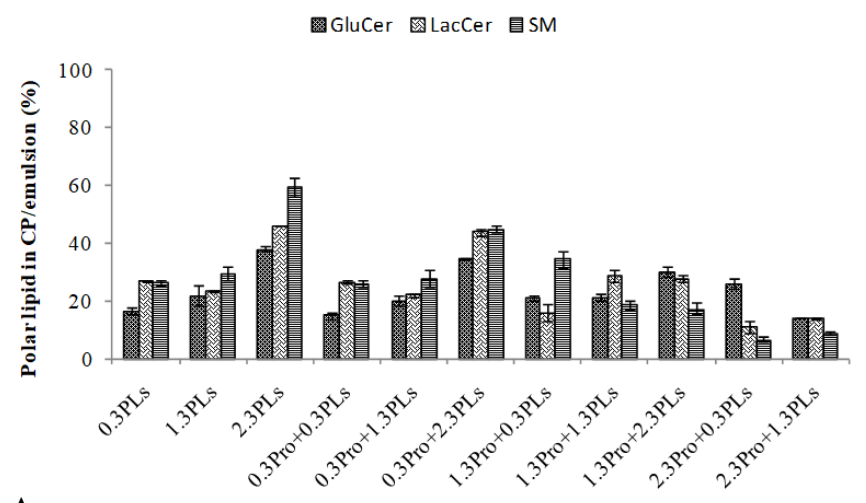

A

Combination of proteins and polar lipids (wt\%)

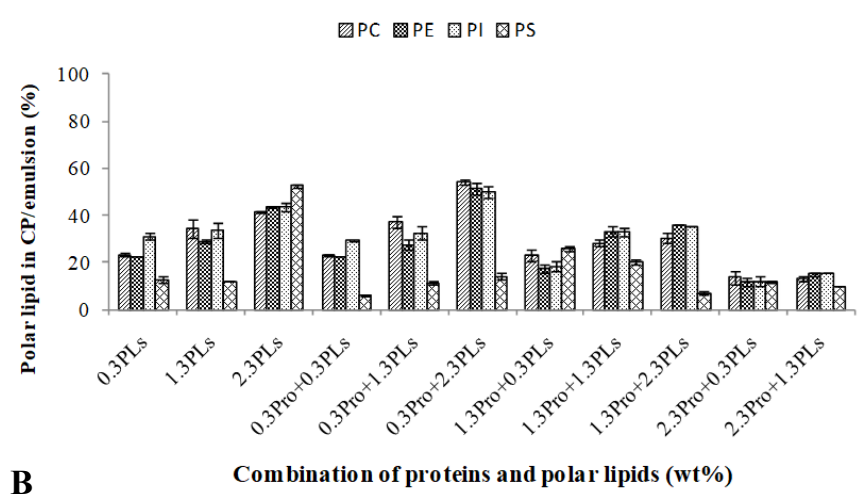

Figure 5. Adsorption of (A) sphingolipids (GluCer, LacCer, SM) and (B) glycerophospholipids (PI, PE, PS and PC) at the droplet surface of emulsions prepared with various concentrations of proteins and PLs. CP $=$ cream phase

because XO and BTN are capable of being acylated with fatty acids and BTN can also be acylated with phosphate (Keenan et al., 1982; Spitsberg and Gorewit, 1997; Mather, 2000). In another study by Singh (2006) it prospected that oleic-, palmitic- and stearic acid are the main fatty acids bound with both XO and BTN. Therefore, they can be involved in the formation of a protein-PLs complex, which could be the reason for this behavior. An opposite trend was observed with caseins; the adsorbed caseins at the surface strongly decreased with increasing the concentrations of PLs in the system, from 0 to 2.3\% (Figure 4B). Fang and Dalgleish (1993) reported that the presence of phospholipids decreased the amount of protein necessary to cover the oil-in-water interface. In those studies, the authors described a synergistic effect of proteins and phospholipids, whereby phospholipids adsorbed in the gaps present at the interface, caused by the presence of an insufficient amount of proteins. Depending on their molecular nature, PLs can displace proteins from the interface and/ or bind to proteins, inducing the formation of new surface-active molecules (Nylander et al., 1997). Our results showed that $\mathrm{SM}$ was more effective in removing the casein from the interface (Figure 4B and Figure 5A). This is in agreement with the finding of Krisdhasima et al. (1993) who reported that casein had a higher affinity for being adsorbed at the hydrophilic surfaces. Since SM is a water-soluble polar lipid, it may displace casein more effectively. The low proportion of adsorbed caseins at the surface of emulsions, prepared with a combination of $0.3 \%$ proteins and $2.3 \%$ PLs, could result from a displacement of caseins by certain PLs. The results in Figure 4 show that, at a low protein concentration $(0.3 \%)$, the presence of PLs in emulsions affects the competitive adsorption between caseins and MFGMspecific proteins at the interface. The incorporation of $\mathrm{XO}$ and BTN at the interface increased, while the incorporation of caseins decreased.

When no proteins were present, or when used at $0.3 \%$, the adsorption of all polar lipid components at the surface increased with increasing the concentrations of PLs from 0.3 to $2.3 \%$. At $2.3 \%$ proteins, their concentrations in the emulsion did not affect the adsorption of polar lipids. In addition, the proportion of polar lipids adsorbed at the surface in emulsions containing $2.3 \%$ proteins was lower than that of emulsions prepared with $1.3 \%$ proteins.

Identifying the overall competitive adsorption 
behavior of proteins and PLs at the oil-water interface was difficult because of the changes in the proportion of individual adsorbed proteins and PLs when emulsions were prepared with different concentrations of proteins and PLs. To identify the relationships between the adsorption behavior of proteins (e.g. XO, BTN, caseins, $\beta$-LG and $\alpha$-LA) and PLs (e.g. GluCer, LacCer, PI, PE, PS, PC and SM) at the droplet surface, multivariate principle components analysis (PCA) was applied and the results are shown in Figure 6.
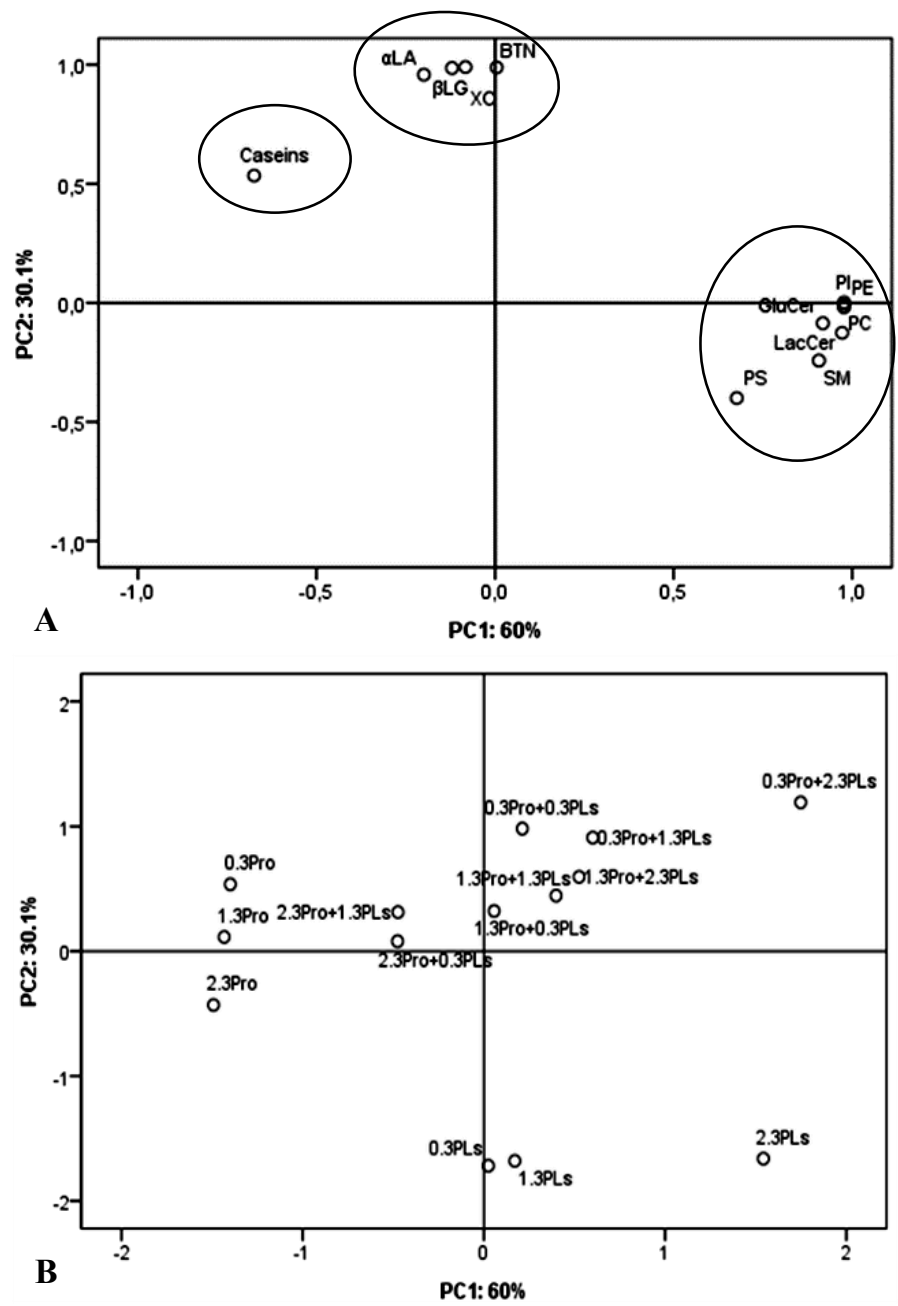

Figure 6. Principal component analysis (PCA) loadings for (A) the proportion of adsorption of proteins and PLs at the interface of oil-in-water emulsions and scores for (B) emulsion samples.

The first principal component (PC1) explained $60.0 \%$ of the variation across the samples, whereas the second principal component (PC2) explained $30.1 \%$ of the variance. In Figure 4A, it is shown that the surfaceadsorbed proportion of GluCer, LacCer, PI, PE, PS, PC and $\mathrm{SM}$ is positively correlated with $\mathrm{PC} 1$, whereas the adsorbed caseins are negatively correlated with PC1. In addition, the adsorbed XO, BTN, caseins, $\beta$-LG and $\alpha$ LA positively correlated with PC2. Consequently, these response factors can be divided into three groups, based on their distribution in Figure 6A. In Figure 6B, the sample points are plotted, increasingly toward the positive side of the PC2 axis with the decrease in the protein concentrations $(2.3 \%$ to $0.3 \%)$ in the emulsions. This indicated that the surface-adsorbed proportion of MFGM-specific proteins (i.e. XO and BTN) and whey proteins (i.e. $\beta$-LG and $\alpha$-LA) decreased with increasing protein concentrations from 0.3 to $2.3 \%$, regardless of the concentrations of polar lipids. In contrast, the proportion of surface-adsorbed of polar lipid components and caseins are affected by both the proteins and polar lipids concentrations. By increasing the PLs concentrations $(0.3$ to $2.3 \%)$ and decreasing the protein concentrations ( 2.3 to $0.3 \%$ ), the sample points were plotted increasingly toward the positive side of the PC1 axis. Among 14 emulsions, emulsions prepared with either $2.3 \%$ PLs alone or in combination with $0.3 \%$ proteins, are strongly positively correlated with $\mathrm{PC} 1$. The difference in the type of proteins (i.e. MFGM-specific proteins, caseins and whey proteins), the HLB of PLs, the total proteins and PL concentrations in the emulsion may play some role in this contrast. Depending on their molecular nature, PLs can displace proteins from the interface or/and bind to proteins inducing the formation of new surface-active molecules (Nylander et al., 1997).

In conclusion, the PCA result of our study shows that the adsorption of species of PLs (i.e. GluCer, LacCer, PI, PE, PS, PC and SM) at the interface revealed a strong negative correlation to the amount of adsorbed caseins at the surface. This means that a higher amount of adsorbed GluCer, LacCer, PI, PE, PS, PC and SM at the surface resulted in a lower amount of adsorbed caseins. The amount of XO, BTN, $\beta-\mathrm{LG}$ and $\alpha$-LA adsorbed at the surface, was mainly affected by the protein concentrations present in the emulsions.

In the present study, only the emulsifying properties of MFGM group components or fractions (i.e. MFGM proteins and PLs), were studied. More work should be conducted on the emulsifying properties of individual MFGM-specific proteins (e.g. MUC1, PASIII, PAS6/7, ...) in an oil-in-water emulsion, as no data on this topic are available in the literature. For a complete view on the role of all specific protein components of MFGM adsorbed at the interface, standards are essential. These could possibly be obtained by the purification of each individual protein using different techniques.

\section{Conclusion}

Results from this work evidenced that MFGM proteins and PLs and their concentration can affect the emulsifying properties of oil-in-water emulsions. It was found that at a low emulsifier concentration $(<2.3 \%$ in total), the combination of both proteins and PLs in oilwater emulsion leads to a positive interaction between proteins and PLs, resulting in an enhancement in their 
emulsifying properties, especially in the formation of an emulsion with no sign of aggregation and low apparent viscosity. The surface characteristics and adsorption behavior at the surface of oil-in-water emulsions were affected by the concentration and the type of emulsifiers (i.e., MFGM protein and PL concentrate) used. The presence of PLs affected the competition between caseins and MFGM-specific proteins (i.e., XO and BTN), for being adsorbed at the oil droplet surface. However, no competitive displacement between proteins and PLs was observed at the surface of these emulsions. At an identical concentration, MFGM protein concentrate had a better emulsifying ability than PL concentrate. In conclusion, the use of MFGM protein concentrate from reconstituted buttermilk in the preparation of emulsions has a greater impact at the oilin-water interface compared to the PL concentrate.

\section{Acknowledgments}

This work was financially supported by MOET (Ministry of Education and Training) (project number: 322) scholarship of Viet Nam. The authors would like to thank FrieslandCampina (Lummen, Belgium) for providing the buttermilk powder.

\section{References}

Chanamai, R. and McClements, D.J. (2000). Dependence of creaming and rheology of monodisperse oil-inwater emulsions on droplet size and concentration. Colloid Surfaces A, 172(1-3), 79-86. https:// doi.org/10.1016/S0927-7757(00)00551-3

Dickinson, E. and Golding, M. (1997). Depletion flocculation of emulsions containing unadsorbed sodium caseinate. Food Hydrocolloids, 11(1), 13-18. https://doi.org/10.1016/S0268-005X(97)80005-7

Fang, Y. and Dalgleish, D.G. (1993). Casein adsorption on the surfaces of oil-in-water emulsions modified by lecithin. Colloids and Surfaces B, 1(6), 357-364. https://doi.org/10.1016/0927-7765(93)80030-3

Ihara, K., Ochi, H., Saito, H. and Iwatsuki, K. (2011). Effects of buttermilk powders on emulsification properties and acid tolerance of cream. Journal of Food Science, 76(2), C265-271. https:// doi.org/10.1111/j.1750-3841.2010.02017.x

Kanno, C., Shimomura, Y. and Takano, E. (1991). Physicochemical properties of milk-fat emulsions stabilized with bovine-milk fat globule-membrane. Journal of Food Science, 56(5), 1219-1223. https:// doi.org/10.1111/j.1365-2621.1991.tb04738.x

Keenan, T.W., Heid, H.W., Stadler, J., Jarasch, E.D. and Franke, W.W. (1982). Tight attachment of fatty acids to proteins associated with milk lipid globule membrane. European Journal of Cell Biology, 26(2), 270-276.

Krisdhasima, V., Vinaraphong, P. and Mcguire, J. (1993). Adsorption kinetics and elutability of $\alpha$ lactalbumin, $\beta$-casein, $\beta$-lactoglobulin, and bovine serum albumin at hydrophobic and hydrophilic interfaces. Journal of Colloid and Interface Science, 161(2), 325-334. https://doi.org/10.1006/ jcis. 1993.1474

Le, T.T., Miocinovic, J., Nguyen, T.M., Rombaut, R., Van Camp, J. and Dewettinck, K. (2011). Improved solvent extraction procedure and HPLC-ELSD method for analysis of polar lipids from dairy materials. Journal of Agricultural and Food Chemistry, 59, 10407-10413. https:// doi.org/10.1021/jf200202d

Mather, I.H. (2000). A review and proposed nomenclature for major proteins of the milk-fat globule membrane. Journal of Dairy Science, 83, 203-247. https://doi.org/10.3168/jds.S0022-0302(00) 74870-3

Miura, S., Mutoh, T., Shiinoki, Y. and Yoshioka, T. (2006). Emulsifying properties of phospholipids in the reconstitution of cream using butter oil. European Journal of Lipid Science and Technology, 108(11), 898-903. https:// doi.org/10.1002/ejlt.200600109

Murray, B.S. and Dickinson, E. (1996). Interfacial rheology and the dynamic properties of adsorbed films of food proteins and surfactants. Food Science and Technology International, Tokyo, 2(3), 131-145. https://doi.org/10.3136/fsti9596t9798.2.131

Nylander, Y., Arnebrandt, T., Bos, M. and Wilde, P. (1997). Food Emulsifiers and Their Applications. In Hasenhuette, G.L. and Hartel, R.W. (Eds). Protein/ emulsifier interactions, p. 95-146. New York, USA: Chapman and Hall. https://doi.org/10.1007/978-14757-2662-6_5

Phan, T.T.Q., Asaduzzaman, M., Le, T.T., Fredrick, E., van der Meeren, P. and Dewettinck, K. (2013). Composition and emulsifying properties of a milk fat globule membrane enriched material. International of Dairy Journal, 29(2), 99-106. https:// doi.org/10.1016/j.idairyj.2012.10.014

Phan, T.T.Q., Le, T.T., van der Meeren, P. and Dewettinck, K. (2014). Comparison of emulsifying properties of milk fat globule membrane materials isolated from different dairy by-products. Journal of Dairy Science, 97(8), 4799-4810. https:// doi.org/10.3168/jds.2014-8030

Phan, T.T.Q., Le, T.T., Van de Walle, D., van der Meeren, P. and Dewettinck, K. (2016). Combined 
effects of milk fat globule membrane polar lipids and protein concentration on the stability of oil-in-water emulsions. International of Dairy Journal, 52, 4249. https://doi.org/10.1016/j.idairyj.2015.08.003

Roesch, R.R., Rincon, A. and Corredig, M. (2004). Emulsifying properties of fractions prepared from commercial buttermilk by microfiltration. Journal of Dairy Science, 87(12), 4080-4087. https:// doi.org/10.3168/jds.S0022-0302(04)73550-X

Scott, L.L., Duncan, S.E., Sumner, S.S. and Waterman, K.M. (2003). Physical properties of cream reformulated with fractionated milk fat and milkderived components. Journal of Dairy Science, 86 (11), 3395-3404. https://doi.org/10.3168/jds.S00220302(03)73943-5

Singh, H. (2006). The milk fat globule membrane-A biophysical system for food applications. Current Opinion in Colloid and Interface Science, 11(2-3), $154 \quad-\quad 163 . \quad \mathrm{https} / / /$ doi.org/10.1016/ j.cocis.2005.11.002

Singh, H. (2011). Aspects of milk-protein-stabilised emulsions. Food Hydrocolloids, 25(8), 1938-1944. https://doi.org/10.1016/j.foodhyd.2011.02.022

Shimizu, M., Yamauchi, K. and Kanno, C. (1980). Effect of proteolytic digestion of milk fat globule membrane proteins on stability of the globules. Milchwissenschaft, 35(1), 9-12.

Sodini, I., Morin, P., Olabi, A. and Jimenez-Flores, R. (2006). Compositional and functional properties of buttermilk: A comparison between sweet, sour, and whey buttermilk. Journal of Dairy Science, 89(2), 525-536. https://doi.org/10.3168/jds.S0022-0302(06) 72115-4

Spitsberg, V.L. and Gorewit, R.C. (1997). In vitro phosphorylated bovine milk fat globule membrane proteins. The Journal of Nutritional Biochemistry, 8 (4), 181-189. https://doi.org/10.1016/S0955-2863 (97)00001-6

Tomas, A. and Paquet, D. (1994). Effect of fat and protein contents on droplet size and surface protein coverage in dairy emulsions. Journal of Dairy Science, 77, 413-417. https://doi.org/10.3168/ jds.S0022-0302(94)76967-8

Vanderghem, C., Bodson, P., Danthine, S., Paquot, M., Deroanne, C. and Blecker, C. (2010). Milk fat globule membrane and buttermilks: from composition to valorization. Biotechnologie, Agronomie, Société et Environnement, 14(3), 485500.

Walstra, P., Wouters, J.T.M. and Geurts, T.J. (2006). Dairy Science and Technology Handbook. $2^{\text {nd }}$ ed. United Kingdom: Taylor and Francis Group.
Wong, P.Y.Y. and Kitts, D.D. (2003). A comparison of the buttermilk solids functional properties to nonfat dried milk, soy protein isolate, dried egg white, and egg yolk powders. Journal of Dairy Science, 86(3), 746-754. https://doi.org/10.3168/jds.S0022-0302(03) $73655-8$ 